\title{
On Strategy of Effective Integration of Chinese and Western Culture in Foreign Language Teaching
}

\author{
Bo Wang \\ XingTai University, Xingtai, 054001, China
}

Keywords: Foreign language learning; Sino-Western cultural differences; Development of education

\begin{abstract}
Language is a tool for people to communicate and a symbol of national history and culture. Culture origins, religions and customs of different countries are various, so are the local languages. So, communication barriers caused by differences between Chinese and Western cultures often emerge in foreign language teaching. To teach foreign language better, this article, by studying the significance of integration of Chinese and Western cultures on teaching, focuses on English teaching and analyzes the actual role of integration of Chinese and Western culture in foreign language teaching.
\end{abstract}

\section{Status of Foreign Language Development Foreign Language Learning}

According to the statistics of Linguistics and Language Communication Tools Handbook, there are total 5651 kinds of languages in the world. Language is a symbol of history and culture of a country or a society, and a tool for people to communicate. English, the world's most widely used language, existing as the standard language for a number of international organizations, such as the European Union and the British Commonwealth, plays an important role on the international stage. Currently, the trend of globalization strengthens gradually. Since China's reform and opening up in 1978, China's role on the international stage has become increasingly important.

To further enhance the communication between China and Western countries, Chinese citizens need to mater the usage of English. In the past decade, the total English speaking population surged dozens of times, with a total learning population of foreign language of more than 5 million. According to analyses of related experts, illiterate in the future may refer to those who do not know a foreign language, and this kind of people is subject to become unemployed. So foreign language learning becomes a necessity for people's own development and future.

\section{Foreign Language Teaching}

Nowadays, people put more and more importance on foreign language; foreign language teaching is an important part of language learning, teaching range extending continuously. Foreign language teaching means teaching non-native language to people who have already mastered their mother tongue in a community, which usually takes place in classroom. Foreign language teaching in our country can be traced back to Ming dynasty, mainly teaching modern language. But the choice of language was usually influenced by educational system and social needs. For example, in Qing dynasty, most of secondary curriculum referred to German's and Japan's curriculum, while on foreign language teaching, Japanese and English first, and then Germany and English, which was related to the external environment of world order in First World War and Second World War. After the foundation of People's Republic of China, because the influence of the nature of our state, learning Russian came first, and then English because of the following development of international communication. 


\section{Difficulties in Foreign Language Teaching}

Even though nowadays foreign language teaching grows vigorously, there are still 5 problems existing in foreign language teaching:

The conundrum of foreign language teaching is differences between Chinese and Western cultures.

Every country has its own culture and tradition. Our country has a "River Civilization” of a distant origin and a long development, originating from reaches of Yellow River with emphasis on farming, the overall thoughts of which is conservative. However, Western culture emerged from commerce, the thought of which is open. This condition makes the primary difference in thoughts and culture. Cite a simple example: a new-come foreign teacher would teach your class and you, as an introducer, introduce him to students that "There is a pretty teacher......", you may believe that you praise the new foreign teacher properly but the foreign teacher doesn't think so. The reason is that foreigners attach more importance on ability and presenting their professional title and ability is their comfortable way to be introduced. It is a simple problem of the differences between Chinese and Western cultures, which lead to the differences in language communication.

\section{The conundrum of foreign language teaching is caused by ignoring the actual use of English}

Language comes into being from daily communication practice, but it also gets enrichment and development in the use. Take the recent popular US version The Legend of Zhen Huan as an example, "ten feet in red" has been translated into "the scarlet red (sinful red)", which are newly created words in the actual communication of Chinese and Western cultures. But foreign language teaching only pays attention to the written grammar and structure, ignoring the application in actual communication. So the cruel phenomenon becomes normal that students who have passed CET 4 and CET 6 couldn't say "Hello" to foreigners.

\section{The conundrum of foreign language teaching is caused by dull and single teaching method.}

The common method of foreign language teaching is only paying attention to teacher's explaining, grammar patterns and analysis of article, which loses sight of playing the initiative of students and increasing the classroom fun. This is one of the problems of teaching methods. Not interested in learning English may lead students to passively accept knowledge, as a "spoon-fed" education. Therefore, we should overcome this problem by adding richness and vividness in classroom.

\section{The conundrum of foreign language teaching is caused by low level of teachers' quality}

In the situation of low teaching level, with the status quo that teachers' quality is incomprehensive and teachers' experience is not rich, it is very difficult for teachers to impart their knowledge and learning experience to students. And it is also difficult for students to learn useful knowledge from teachers in turn. Therefore, to make students lean foreign language better, improving teachers' quality is also crucial.

The conundrum of foreign language teaching is caused by failure to teaching students in accordance with their aptitude.

There are a thousand Hamlets in a thousand people's eyes. So is learning foreign language. Different person has different knowledge, different family environment and different education background, which affect everyone's learning ability. Therefore, in the process of foreign language learning, some people can always easily master vocabulary and grammar, however, some people find it is puzzling. This is closely related to their quality and ability. 


\section{Development Direction of Foreign Language Teaching of the Integration of Chinese and Western Cultures}

The conundrum of foreign language teaching is mainly caused by differences emerging in Sino-Western communication, so in foreign language teaching, there are 6 development directions as followed:

\section{Diversified teaching}

First, foreign language teaching is not just educational guidance to only a language, but also should be the understanding of a country's national condition and culture. So, foreign language teaching couldn't be limited to the classroom, and students should be promoted to have diversified learning. Secondly, the current foreign language teaching methods are dull and signle. Teachers should use multimedia, PPT and other new media in classroom. Teachers should use different teaching methods to train students' divergent thinking and advocate students to learn in thinking, so that students can grasp the language better.

\section{Teaching for understanding}

The ability to accept and learning styles of different students are different. Education to students should not be confined to asking students to memorize a few more words or to read more articles, but should focus on cultivating students' independent thinking. Only students truly understand the benefits of learning a foreign language and really play their own initiative can them accelerate the speed of learning a foreign language.

\section{Innovative teaching}

Take "memory more and practice more" which is advocated in the current foreign language teaching into consideration, students can only learn a foreign language through the painful and machinery exercises. But in fact foreign language is a practical communication tool. By advocating students to speak more in classroom and practice more outside the classroom is the real good way to learn a foreign language. We should change the old teaching ideas and promote the use of scientific and innovative ways to guide students.

\section{Broadening teaching}

Currently, the western information students know is only from books and is relatively limited. But Western values and cultures couldn't be summarized in only one book. Teachers should take the initiative to guide students to read more extracurricular material, listen VOA, and appreciate Western films and television works to broaden their knowledge and to form a better understanding of the differences between Chinese and Western culture, so as to master foreign language better.

\section{Contrast teaching}

There are differences between Chinese and Western culture, which also affect the used of Chinese and foreign language. In daily education, emphasizing on contrast teaching would be more vivid than introducing Western culture alone. In simple terms, teachers can compare Chinese New Year with Westerners' Christmas Day when introducing it. Westerners attach importance to Christmas Day just as Chinese think highly of Spring Festival. In this way, students can not only achieve a better understanding of the meaning of Christmas, but also learn the English term for Chinese New Year.

\section{Teaching by experience}

When learning a foreign language, what students need most is the guidance of senior's experience, just like a freshmen entering a college wants friendly seniors to lead him, it is important for students to have a good instructor when learning a foreign language. Teacher can teach by precept and example, talk about the difficulties he encountered when learning the foreign language, and share his own experience. Encouraging students to talk with teacher can not only reduce the problems students encountered, but also can promote feelings of teachers and students. So why not try it? 


\section{Foreign Language Teaching Method of Integration of Chinese and Western Culture}

Through the analysis of problems in foreign language teaching, we know that there are both objective and subjective difficulties in foreign language teaching, including the subjective reasons like students' quality and teachers' teaching quality, the objective reasons as barren teaching content, ignoring of practical usage and differences between Chinese and Western cultures. Next, I would put forward some feasible teaching methods according to the specific analysis of differences between Chinese and Western culture in foreign language teaching:

\section{Increase students' knowledge of Western culture and history background}

Nowadays, students usually only know the article explained in classroom but does not know the background of the article. So even though a student has being learned a foreign language for many years, he knows nothing about the country which use the foreign language. There is a joke: when asked to list out two English-spoken countries, students didn't know that US and UK are the largest two English-spoken countries. We have to say it is a pity for foreign language teaching. When teaching some articles about Western welfare system, teachers can expand some knowledge about Western welfare system to students. Only through teachers' guidance in classroom, can students enhance their understanding of Western culture and use English and other foreign language to communicate better.

\section{Encourage students to improve their own learning ability}

When learning foreign language, students are always follows to teachers, holding that only doing the practice what teacher asks and no more. In fact, learning depends on student himself, just as an old Chinese saying goes that "The master teaches the trade, but the apprentice's skill is self-made". Learning counts on student's subjective initiative. Only if student plays his subjective initiative can he studies and works actively, fearing neither hardship nor tiredness, and master the foreign language better.

\section{Teachers should expand teaching levels and categories, and apply multimedia to Sino-Western culture teaching}

Chinese and foreigners have different thoughts and values, which lead to the difficulty in foreign language teaching and learning. Take that Chinese is accustomed to ask other's salary as an example. Salary is a secret of foreigners which one does not want to publish. So, in daily teaching, teachers should pay attention to contrasting education of Sino-Western daily culture, and teach students some frequently used sentences and take notice of culture differences. Only in this way can students learn culture difference better and learn foreign language better. When teaching this part, teachers should not be confined to lecture, but to show PPT to students to make the teaching more interesting and to let students understand deeply the difference in language usage.

\section{School should hire foreign teacher to cooperate teaching}

Inadequate teaching stuff is always a problem in foreign language teaching in our country. Hiring foreign teacher can not only let students listen the right pronunciation of foreign teacher who treat the foreign language as his mother tongue, but also let students understand the true foreign culture through communication with foreign teacher. Foreign language teaching can be performed better only through correcting foreign language learning from the foundation of pronunciation.

\section{Teachers should ask student to read more about Chinese and foreign companies}

Human resources are very important in society nowadays. An inter-disciplinary talent should maintain not only excellent language ability, but also the ability to see the market clearly. Learning of successful companies examples in Sino-Western culture and analyzing the development of company can increase student's comprehension of foreign article of utility type and cultivate student's elaborative faculty. Take a Volvo advertisement I used to see as an instance: the advertisement is in English; the person who can do the splits best in the world is hired to do the splits between two trucks 
to testify the super stability. Just showing this video to students, they can know more about how to write car's performance, Volvo, the person who can do the splits best in the world in English. They may even find more English video to learn initiatively. This can let students learn the difference of Chinese and Western cultures and enhance the effective way of foreign language teaching.

\section{Foreign language teaching couldn't be confined to classroom}

Teachers should find more opportunities to encourage students to walk out classroom to learn the world. A person's heart should be as big as the world. Flower of innovation couldn't bloom if thoughts are imprisoned. Foreign language learning is the same. If a person truly wants to learn a foreign language well, it is the best choice to get into a foreign-language-using environment. One can learn a foreign language better in using and applying the foreign language. This is one of the most important reasons that foreign language teaching couldn't be confined to classroom and should walk into life. There is often an English corner in colleges and universities, teachers should encourage students to actively take part in the study of English corner, talking with foreigners and learning mutual cultures, which is the incarnation of diversification of foreign language teaching methods.

\section{Conclusion}

In summary, through the analysis of existing problems in foreign language teaching, we find that the main reason for these problems is difference between Chinese and Western culture. As for the situation mentioned above, we should carry out studies on foreign language teaching strategy of integration of Chinese and Western culture and come up with the future development direction of foreign language teaching: diversification, understanding, innovation, broadening and contrasting; at the same time, we should add new factors in teaching method continuously, which is the new method and new trend of foreign language teaching. Nowadays, the world gradually evolves to globalization, Sino-Western cultures develops in clashes. But foreign language teaching is a process of long-term development. Foreign language teaching should be down-to-earth and looks forward to the future.

\section{Acknowledgments}

Title of this article: On Strategy of Effective Integration of Chinese and Western Culture in Foreign Language Teaching. Project No.: MSJD2014KTY023.

\section{References}

[1] Zhu Yan. Some Problems in Foreign Language Teaching. Higher Education Forum. 2013(4):11-13

[2] Zhen Yanhua. Culture Clash between Chinese and Western Culture and Consciousness of Culture. Northern Forum.2012(6):13-18

[3] Wang Zhiling. Gu Ping. Enlightenment of Cultural Differences on Trans-cultural foreign language teaching .Foreign Language and Literature(Journal of Sichuan International Studies University).2013(2):10-15

[4] Gao Qiang. The Essential Characteristics of Teacher's Language and Its Role in Foreign Language Teaching. Heilongjiang Researches on Higher Education.2013 (5):10-25

[5] Han Shuqin. Theory, Practice and Introspection of Foreign Language Culture Teaching Theory . Foreign Language World.2014(3):33-43

[6] Lin Dajin. On Trans-culture Communication: Communicate with British and American . Fuzhou: Fujian People’s Press.2013. 